\title{
Review Article: Herbal Approach for Obesity Management
}

\author{
C. V. Chandrasekaran ${ }^{1,2 *}$, M. A. Vijayalakshmi ${ }^{2}$, K. Prakash ${ }^{1}$, V. S. Bansal ${ }^{2}$, J. Meenakshi ${ }^{1}$, \\ A. Amit ${ }^{1}$ \\ ${ }^{1}$ R\&D Centre, 5B, Veerasandra Industrial Area, Natural Remedies Pvt. Ltd., Bangalore, India; ${ }^{2}$ Center for Bioseparation Technology, \\ VIT University, Vellore, India. \\ Email: ${ }^{*}$ cvc@naturalremedy.com, cvctox@gmail.com
}

Received May $1^{\text {st }}, 2012$; revised May $30^{\text {th }}, 2012$; accepted June $10^{\text {th }}, 2012$

\begin{abstract}
Obesity, a complex interplay between environmental and genetic factors and is associated with significant morbidity and mortality. Usage of herbs for the management of obesity in the recent times is attracting attention. A web and manual based literature survey was conducted to assess the amount of information available on the herbal products for weight management. Traditional literature, PubMed, Scopus, Google scholar databases were screened up to February 2012. The search words were "obesity", "herbal medicine/products/extracts", "medicinal plants", "traditional medicine", "Ayurvedic medicine" without narrowing/limiting searching words or elements. Publications only with abstracts/full articles and books were reviewed in the search. Based on the available literature, for many of the herbal and weight loss products, there is little published information and there have been no clinical trials or the level of evidence is limited. Our literature survey also indicated that these herbal products fall under an acceptable level of evidence or with no scientific background at all, or they have a scientific rational but not to an acceptance level. Attempts were made in the review to define the features of possible herbal weight loss product. An ideal herbal anti obesity product should reduce the weight by $10 \%$ over placebo of treatment by showing an evidence of improvement of bio markers like blood pressure, lipids and glycemia without any side effects.
\end{abstract}

Keywords: Morbidity; Ayurveda; Obesity; Literature Survey; Medicinal Plants; Herbal Products; Weight Management

\section{Introduction}

Accumulation of fat over the limit led to ill/adverse effect in the body known as obesity. Body mass index (BMI) is an index of weight-for-height that is commonly used to classify overweight and obesity in adults. The World Health Organization (WHO) definition is: 1) A BMI greater than or equal to 25 is overweight and, 2) A $\mathrm{BMI}$ greater than or equal to 30 is obesity. BMI provides useful population-level measure of overweight and obesity as it is the same for both sexes and for all ages of adults. However, it should be considered as rough guidance because it may not correspond to the same degree of fatness in different individuals.

Obesity and overweight occurs due to imbalance between calories consumed and calories utilized. Globally, there have been two reasons for overweight and obesity: 1) an increased intake of energy-dense foods that are high in fat, salt and sugars but low in vitamins, minerals and other micronutrients; and, 2) a decrease in physical activity due to the increasingly sedentary nature of many forms of work, changing modes of transportation, and

"Corresponding author. increasing urbanization [1,2]. Changes in dietary and physical activity patterns are often results from sedentary lifestyle, not sleeping enough, endocrine disruptors, such as some foods that interfere with lipid metabolism, medications that make patients put on weight, medical and psychiatric illness and infectious agents.

Overweight and obesity are the fifth leading risk for global deaths. At least, 2.8 million adults die each year as a result of being overweight or obese. In addition, $44 \%$ of the diabetes burden, $23 \%$ of the ischaemic heart disease burden and between $7 \%$ and $41 \%$ of certain cancer burdens are attributable to overweight and obesity. WHO global estimates for the year 2008, reported 1.5 billion people were overweight, of these, over 200 million men and nearly 300 million women were obese. Overall, more than one in ten of the world's adult population was obese [1,3].

In 2010, around 43 million children under five were overweight. Overweight and obesity are now on the rise in low and middle income countries, particularly in urban settings. Close to 35 million overweight children are living in developing countries and 8 million in developed countries. Childhood obesity is associated with a higher 
chance of obesity, premature death and disability in adulthood. But in addition to increased future risks, obese children experience breathing difficulties, increased risk of fractures, hypertension, cardiovascular diseases and psychological effects [4].

Overweight and obesity are linked to more deaths worldwide than underweight. For an example, $65 \%$ of the world's population live in countries where overweight and obesity kill more people than underweight (this includes all high-income and most middle-income countries). Obesity is a major health threat. The extra weight puts added stress on every part of individual's body. People with obesity are at risk for these health problems: Bone and joint problems due to extra weight puts strain on the bones and joints. This can lead to osteoarthritis, a disease that causes joint pain and stiffness, gallstones and liver problems, heart attack from coronary heart disease, congestive heart failure, and stroke, high blood cholesterol and triglycerides (dislipidemia or high blood fats), high blood pressure (hypertension), high blood sugar (glucose) or diabetes, stopping breathing during sleep (sleep apnea). This can cause daytime fatigue or sleepiness, poor attention, and problems at work.

Obesity is recognized as the most crucial risk factor for type 2 diabetes. Obesity, in particular intraabdominal adiposity, is associated with increased free fatty acid (FFA) concentrations in blood plasma which exercise a major negative effect on insulin sensitivity in both muscle and liver. Besides insulin resistance, defective insulin secretion is a prerequisite for the development of type 2 diabetes. Both lipotoxicity and glucotoxicity may initiate and enable a vicious circle dependable for the metabolic impairment. Diabetes occurs as a late phenomenon in obesity and is preceded by years of impaired glucose tolerance. The progression to diabetes is indicated by an inability of the B cells of pancreatic langerhans to maintain its high rate of insulin secretion in response to glucose in face of insulin resistance [5]. The partial reversibility of the evolution of obesity towards diabetes is well demonstrated today by lifestyle changes and multidisciplinary weight loss programs [6]. Nature is enriched with plant wealth for all living creatures, which possess medicinal virtues [7]. Anti diabetic activity has been reported in many plants during the last couple of years. Moreover, their mechanism of action differs from that of insulin in that they appear to act as anti-metabolites, capable of blocking the pathway of oxidation of fatty acids. Approximately 343 plants of the world have been tested for the blood glucose which found lowering effect in the laboratory experiments. Of them, 158 species are claimed to be used in traditional system on Indian medicine [8].

The chief goal of obesity treatment is to maintain healthy weight. The treatment method to be undertaken often depends on the preferred choice of an individual undergoing treatment as well as the level of obesity. Common treatment measures include the following methods, dietary changes, exercise and activity, behavior change, prescription weight-loss medications and weightloss surgery [2].

The preferred treatment modality for weight loss is dieting and physical exercise. But due to busy schedules and sedentary lifestyle follow-up the first two methods never seems to be practiced in a regular manner. On the other hand weight loss surgery runs out of the option considering the cost involved. There is a gradual shift towards an increase use of drugs. Drugs are pharmacological agents that reduce or control weight. These drugs alter one of the fundamental processes of the human body, weight regulation, by altering appetite, metabolism, or absorption of calories. Only one anti-obesity medications orlistat is currently approved by the FDA for long term use. It reduces intestinal fat absorption by inhibiting pancreatic lipase [3]. Rimonabant, a second drug often referred to as "the munchies", had been approved in Europe for the treatment of obesity but has not received approval in the United States and Canada due to safety concerns [9]. Sibutramine, which acts on the brain to inhibit deactivation of the neurotransmitters, thereby decreasing appetite was withdrawn from the United States and Canadian markets in October 2010 due to cardiovascular side effects [6]. Because of potential side effects, it is recommended that anti-obesity drugs only be prescribed for obesity where it is hoped that the benefits of the treatment outweigh its risk [10].

The use of allopathic and pharmacological drugs has become a popular means to overcome excess weight gain [11]. While these drugs generally are effective, severe adverse toxicities may limit their overall usefulness [12, 13]. A nutritional based intervention is being hailed as an inexpensive alternative to aid weight loss, and weight management [14]. Medicinal herbal supplements are being extensively utilized due to their effectiveness in managing many chronic disorders. They are cost-effective, and exert less to no toxic side-effects in comparison with many chemically synthesized drugs [15]. Accordingly, recent preliminary reports suggested that herbs with a long history of use and other natural substances less likely to produce severe toxicity might be effective in reducing appetite and promoting significant weight loss are encouraging [16].

\section{Obesity and Psychiatric Co-Morbidity}

The evidence for the interplay between certain mental illnesses (binge-eating, anxiety, mood disorders) and obesity is bidirectional [17]. Various demographical groups suggest that social or cultural factors may moderate or mediate the association between obesity and mood dis- 
orders. Population with a psychiatric disorder is at higher risk for overweight and obesity than healthy ones [18-20]. At present there is no clear link concluded between obesity and psychopathology, and whether the possible psychological disorders are a cause or a consequence of obesity has not yet been clarified either [21]. Studies do portrays that certain psychological disorders seem to be more common in obese people, such as depression, anxiety, substance abuse, etc., although the direction of the explanatory relation is not clear; moreover, the opposite result has also been found [22]. Furthermore, there are studies which determine high prevalence rates of mental disorders in obese patients seeking treatment, suggesting the psychiatric evaluation of obese patients as a routine practice [23].

The mere evidences of likely co morbid psychopathology means that the practitioner must consider its assessment in obesity cases, and include a plan for a psychiatric and/or psychological therapeutic intervention. Over the past decade, there has been a great increase in the use of complementary treatment such as herbal remedies for relieving the psychiatric symptoms of obesity and the related morbidities [21,22]. Lee et al. has suggested the use of Ob-X, a mixture of three herbs Melissa officinalis L. (Labiatae), Morus alba L. (Moraceae), and Artemisia capillaris Thunb. (Compositae) for regulating hyperlipidemia [23].

\section{Herbs Recommended for Obesity}

Evidences are emerging to support that an increasing consumption of herbs are effective strategy for obesity control and weight management. Usage of plants and plant products has potential to keep the increasing prevalence of metabolic syndrome in control. There are few drugs in the market to prevent/manage obesity but there are the costs, efficacy and side effects to consider. For centuries people across the countries have been using natural products as plant based dietary supplements for weight control [24].

\section{Traditional Medicine and Obesity}

Ayurveda (Ayur $=$ life, Veda $=$ knowledge), which is "Science of Life", originated from the Vedic times and is a part of holistic health care system. The chief source of ancient Indian Aryan culture and medicine are the four Vedas that are traditionally believed to be revealed to the sages by Brahma (the creator) some 6000 years before Christian era. Ayurveda's primary emphasis is on preservation and promotion of health, it also provides treatment for disease. Many undesirable constitutions (about eight) in the body are mentioned in "Charaka Samhita", an authentic source of ayurveda. Obesity or "Medoroga" is one among them. It is said that it is comparatively easy to help an underweight person, rather than an overweight person. The overweight problem can be due to an actual increase in the fat component (Meda Dhatu), or it can be due to malfunctioning. These, accordingly, will need different approaches. In very few cases it can be an offshoot of other metabolic disorders. We have reviewed the available ayurvedic/traditional texts books [25-28] for searching plants which are indicated for obesity. The detailed list of plants has been depicted in Table 1.

\section{Modern Literature and Obesity}

A huge number of herbal supplements are currently present in the market for the management of obesity, although not all of them have the same effect, reason being, supplements targeting different molecules thereby following unique mechanism of action varying completely from the other. The basic principle underlying the mode of action of anti-obesity supplements is regulating the energy balance in the body, which is the balance between energy intake and expenditure. For the convenience of explaining/understanding different studies follow different approaches of categorizing the mechanism, either on the basis of the effect of the drug on nervous system or the effect of a supplement on physiological functions/ behavior.

Ample of review on anti-obesity supplements have categorized their mechanism of action primarily on the basis of the activity they regulate. For an example, Yun et al. [29] classified the mechanism of anti-obesity action of natural supplements on the basis of the effect they produce 1) decreased lipid absorption, 2) decreased energy intake, 3) increased energy expenditure, 4) decreased pre-adipocyte differentiation and proliferation, or 5) decreased lipogenesis and increased lipolysis. For covering the broader range as well as for the convenience of understanding, Saper et al. [30] classified the mechanism of action of anti-obesity product on the basis of: 1) Increase energy expenditure, 2) Modulation of carbohydrate metabolism, 3) Increase satiety, 4) Increase fat oxidation or reduced fat synthesis, 5) Block dietary fat absorption, 6) Increased water elimination, 7) Enhance mood, 8) Miscellaneous and unspecified. We observed that there is plethora of literature on the mechanism of action of synthetic compounds along with convincing number of clinical studies to stand its safety, but continuous withdrawal of the major drugs (USFDA approved) due to the ill effects [31], paved a way for the growth of dietary supplements as a safe option to cure obesity. At the same time the available literature on mechanism of action of drugs will definitely decrypt the likely molecules and the molecular mechanism by which the active phyto-compounds act on. Like a drug, supplements also can act peripherally, centrally or in combination (peripherally \& 
Table 1. List of herbs indicated for obesity in ayurveda text books.

\begin{tabular}{|c|c|c|}
\hline Botanical name & $\begin{array}{c}\text { Sanskrit/official } \\
\text { name }\end{array}$ & Part(s) used \\
\hline Acacia arabica & Babbula & $\begin{array}{l}\text { Gum, bark, leaf, } \\
\text { fruit-pods }\end{array}$ \\
\hline Acacia catechu & Khadira & bark, heartwood, flower \\
\hline Achyranthus aspera & Apamarga & $\begin{array}{l}\text { Root, seed, leaf, } \\
\text { whole plant }\end{array}$ \\
\hline Aconitum heterophyllum & Ativisha & Root, rhizome \\
\hline Acorus calamus & Vacha & Rhizome \\
\hline Adathoda vasica & Vasa & Leaf, root, flower \\
\hline Aloe vera & Kumari & Leaf, root \\
\hline Alstonia scholaris & Saptaparna & Bark, latex, flower \\
\hline Ananas comosus & Ananas & Fruit \\
\hline Anthocephalus chinensis & Kadamba & Bark, leaf, fruit, root \\
\hline Azadirachta indica & Nimba & All parts \\
\hline Berberis aristata & Daruharidra & Root, stem, fruit \\
\hline Betula utilis & Burja & Bark, nodes \\
\hline Calatropis gigantea & Arka & $\begin{array}{c}\text { Root, bark, flower, leaf, } \\
\text { latex, seed }\end{array}$ \\
\hline Calicarpa macrophylla & Priyangu & Flower, leaf \\
\hline Capsicum annuum & Kutavira & Fruit \\
\hline Cassia tora & Chakramardha & Seed, leaf, root \\
\hline Cedrus deodara & Devadaru & Heartwood oil \\
\hline Cinnamomum zeylanicum & Twak & Bark, leaf, oil \\
\hline Cissampelos pareira & Patha & Root, stem \\
\hline Clerodendrum phlomidis & Agnimantha & Root, bark, leaf \\
\hline Cocus nucifera & Narikela & Fruit, flower, oil, root \\
\hline Commiphora Mukul & Guggulu & Gum-resin \\
\hline Coriandum sativum & Dhanyaka & Whole plant, leaf, fruit \\
\hline Costus speciosus & Kebuka & Rhizome \\
\hline Cuminum cyminium & Jeeraka & Seed \\
\hline Curcuma longa & Haridra & Rhizome \\
\hline Desmostachya bipinnata & Kusa & Root \\
\hline Dolichos biflorus & Kulatta & Seed \\
\hline Embelia ribes & Vidanga & Fruit \\
\hline Emblica officinalis & Amalaki & Fruit \\
\hline Euphobia nerifolia & Snuhi & Latex, stem, leaf, root \\
\hline Ferula nortex & Hingu & Oleo-gum resin \\
\hline Ficus Glomerata & Udumbara & Bark, fruit, latex \\
\hline
\end{tabular}

Continued

\begin{tabular}{|c|c|c|}
\hline Ficus lacor & Plaksha & Bark \\
\hline Ficus religiosa & Ashwattha & Bark, fruit, leaf \\
\hline Ficus rumphii & Asmanthaka & Stem, bark, latex, fruit \\
\hline Garcinia indica & Vrikshamla & Fruit, root, bark, oil \\
\hline Gymnema sylvestre & Meshashringi & Leaf, root, seed \\
\hline Holarrhena antidysentrica & Kutaja & Seed, bark \\
\hline Innula racemosa & Pushkaramula & Root \\
\hline Marsdenia tenacissima & Murva & Root \\
\hline Momordica charantia & Karavellaka & $\begin{array}{l}\text { Fruit, whole plant, } \\
\text { leaf, root }\end{array}$ \\
\hline Moringa oleifera & Sigru & Root, bark, seed \\
\hline Ougenia dalbergioides & Tinisa & Heart wood \\
\hline Picrorhiza kurroa & Katuka & Root \\
\hline Piper chaba & Chavya & Root, fruit \\
\hline Piper longum & Pippali & Fruit, root \\
\hline Piper nigrum & Maricha & Fruit \\
\hline Plumbago zeylanica & Chitraka & Root, bark \\
\hline Pongamia pinnata & Karanja & Fruit, seed, oil, root \\
\hline Pterocarpus marsupeum & Bijaka & Heart wood \\
\hline Randia dumetorum & Madanaphala & Fruit \\
\hline Santalum album & Candana & Heartwood \\
\hline Saussurea lappa & Kushta & Root \\
\hline Sphaeranthus indicus & Munditaka & Whole plant \\
\hline Stereosprmum sauvealens & Patala & $\begin{array}{l}\text { Root, bark, flower, } \\
\text { seed, leaf }\end{array}$ \\
\hline Symplocos racemosa & Lodhra & Bark \\
\hline Terminalia arjuna & Arjuna & Bark, root, leaf \\
\hline Terminalia bellerica & Bibhitaka & fruit \\
\hline Terminalia chebula & Haritaki & fruit \\
\hline Terminalia tomentosa & Asana & Bark, heartwood \\
\hline Thea sinensis & Oolong tea & Leaf \\
\hline Tinospora cordifolia & Guduchi & Stem, root \\
\hline Trachyspermum ammi & Yavani & Fruit \\
\hline Tragia involucrata & Yavasa & Whole plant \\
\hline Tribulus terrestris & Gokshura & Fruit, root, whole plant \\
\hline Trigonella foenum graceum & Methika & Seed, leaf, whole plant \\
\hline Valeriana jatamansi & Tagara & Root \\
\hline Zingiber officinale & Shunti & Rhizome \\
\hline Ziziphus mauritiana & Badara & Root, leaf, fruit \\
\hline
\end{tabular}


central) on the receptors of the nervous system, thereby managing appetite, metabolism (lipid and carbohydrate) or caloric absorption.

In the present review, we surveyed the natural products with anti-obesity potential and reviewed the scientific data, including experimental methodologies, active components, and mechanisms of action against obesity. We classified the mechanism of action of herbs viz., 1) Peripherally acting and 2) Centrally acting.

\subsection{Peripherally Acting Mechanism}

Substances acting peripherally, mediate their effects by reducing the calorie absorption in the gastrointestinal system or by affecting metabolic and/or control systems outside the central nervous system (CNS). One of the way to reduce energy intake is through gastrointestinal mechanisms such as nutrients digestion and absorption [32].

\subsubsection{Lipase Inhibition}

Dietary fat is not directly absorbed by the intestine unless the fat has been subjected to the action of pancreatic lipase. Therefore, pancreatic lipase is one of the most widely studied mechanisms for determining natural products' potential efficacy as anti-obesity agents [32]. Supplement acts in the gut lumen by forming a covalent bond with the active serine site of gastric and pancreatic lipases. By forming the covalent bond, it inhibits these lipases from hydrolyzing the ingested fat into absorbable free fatty acids and monoglycerides. The decreased absorption of ingested fat leads to an overall decreased caloric absorption, in turn leading to weight loss [33].

A wide variety of plants possess pancreatic lipase inhibitory effects, including Panax japonicus [34], Platycodi radix [35], Salacia reticulata [36], Nelumbo nucifera [37]. These pancreatic lipase inhibitory phytochemicals include mainly saponins, polyphenols, flavonoids, and caffeine [38-40]. The most studied natural sources of pancreatic lipase inhibitors are derived from different types of tea (e.g. green, oolong, and black tea). A significantly different type of polyphenols isolated from tea leaves, showed strong inhibitory activity towards pancreatic lipase [41-43]. These polyphenols require galloyl moieties within their chemical structures and/or polymerization of their flavan-3-ols for enhanced pancreatic lipase inhibition [42].

\subsubsection{Adipogenesis down Regulation}

Energy balance and lipid homeostasis is maintained in the body by specialized cells called as adipocytes. Adipocytes primarily store triglycerides and release them in the form of free fatty acid with the change of energy demand in the body [44].
Adipogenesis is a complex process regulated by the expression of several hundred genes. The primary adipogenic transcription factors involved in adipocyte differentiation belongs to the peroxisome proliferator activator receptor (PPAR), C/EBP, and sterol regulatory element binding protein (SREBP) families. PPAR- $\gamma$ expression during differentiation is an important event in adipogenesis process in fat cells [45]. Polyunsaturated fatty acids (PUFAs), a vital components of the phospholipids of cell membranes and acts as a signal transducer regulating adipocyte-specific gene expression involved in lipid metabolism and adipogenesis [46]. Various phytochemicals like quercetin, kaempferol and catechin and dietary flavonoids found in vegetables, fruits, green tea and herbs are reported to down-regulate the adipogenesis-related transcriptional factors PPAR $-\gamma, \mathrm{C} / \mathrm{EBP}-\alpha$ and SREBP-1 and to inhibit adipocyte differentiation during the early stage. Tea catechins and epigallocatechin gallate (EGCG) decreased the weight of subject adipose tissue [47-50].

In addition to showing inhibitory activity against adipocyte differentiation, several naturally-occurring compounds have displayed apoptotic effects on maturing preadipocytes, e.g. phytochemicals, such as esculetin, resveratrol, quercetin, genistein, capsaicin, and conjugated linoleic acids induced apoptosis of maturing 3T3-L1 preadipocytes through suppression of ERK1/2 phosphorylation, activation of the mitochondrial pathway, AMPK activation, or anti-oxidant activity [51-55]. Sirtuin 1 is another target molecule for anti-obesity treatment. Decreased adipogenesis due to resveratrol correlated with increased expression of Sirtuin1, which promotes fat mobilization by repressing PPARc [56,57].

\subsubsection{Thermogenesis}

Excessive adiposity results from an imbalance in energy homeostasis as a result of excessive food intake are not balanced by increased energy expenditure [58,59]. To regulate body weight and energy expenditure, mammalian BAT (brown adipose tissues) establishes non-shivering thermogenesis through dissipation of excess energy as heat [60]. BAT plays an important role in obesity control by controlling energy balance.

The key player in this process is UCP (Mitochondrial uncoupling protein), which discharges the proton gradient generated in oxidative phosphorylation, thereby dissipating energy as heat. Thus, searching for substances that upregulate UCP1 gene expression may be a worthy strategy for achieving obesity control through increased energy expenditure [61]. Yoon et al. has shown that ethanolic extract of Solanum tuberosum, can activate the expression of UCP3 in BAT and the liver and significantly reduced fat weight in HFD-fed rats [62]. Numerous naturally-occurring compounds have been proposed 
as treatments for weight loss via enhanced energy expenditure, including caffeine $[63,64]$ and capsaicin $[57,65]$.

\subsubsection{Lipid Metabolism}

The pharmacological targeting of lipolysis can be envisaged in two different ways. The first strategy entails stimulating triglyceride hydrolysis in order to diminish fat stores, thereby combating obesity. This option requires the associated oxidation of the newly released fatty acids and led to the development of the b3-adrenergic agonists [66]. Some examples of the natural compounds involved in b3-adrenergic receptor activation are the various flavonoids in the leaf of Nelumbo nucifera (NN). Through this pathway, NN extract dietary supplementation resulted in significant suppression of body weight gain in A/J mice fed a HFD [67]. Caffeine, one of the major bioactive components in oolong tea (Thea sinensis) possesses both a positive charge and a hydrophobic area like that of adrenaline. Caffeine's mechanism of lipolytic action might be due to its binding to the phospholipid phosphate groups and the subsequent interactions between the lipase and triglyceride portions of lipid droplets, eliciting lipolysis [41].

\subsection{Centrally Acting Mechanisms}

Body mass can also be maintained by restricting the intake of food. Many products act in a way through their effect on the receptor within the central nervous system thereby developing a sense of satiety within the body.

\subsubsection{Neuropeptide Signaling Modulators}

The dietary intake of humans varies routinely; still weight remains remarkably stable in most humans because overall energy intake and expenditure are exquisitely matched over long periods of time through the process of energy homeostasis $[68,69]$. The status of body energy stores is communicated to the central nervous system by the adiposity-associated hormones leptin, insulin, and possibly selected gastrointestinal (GI) peptides, such as ghrelin [69]. The arcuate nucleus of the hypothalamus, the primary neurnal signaling site for appetite regulating hormones, is mainly composed of two types of neurons:

1) Anorexigenic (appetite suppressing) neuropeptides, pro-opiomelanocortin (POMC) and cocaine- and amphetamine-regulated transcript (CART).

2) Orexigenic (appetite stimulating) neuropeptide, agouti-related peptide (AgRP) and neuropeptide Y (NPY).

Leptin and insulin stimulate the activity of neurons that express the neuropeptide precursor proopiomelanocortin (POMC), while inhibiting neurons that produce the anabolic mediator's neuropeptide Y (NPY) and agoutirelated protein Ghrelin exerts the opposite effects on this circuitry, directly activating NPY/Agrp cells and thereby indirectly silencing POMC cells. Leptin, insulin, and ghrelin communicate with neurons in the hypothalamus and thereby modulate appetite and energy expenditure to regulate body weight. Leptin, Ghrelin and Neuropeptide Y therefore pops up as a hot targets as well as marker for obesity. Green tea extract has been reported to regulate the plasma leptin concentration [70]. Treatments of adlay seed crude extract (ACE) modulated expressions of leptin and TNF-alpha and reduced body weights, food intake, fat size, adipose tissue mass and serum hyperlipidemia in obesity rat fed HFD [71].

Neuropeptide $\mathrm{Y}$ and its many receptors, in addition to stimulating melanocortins and other catabolic pathways, the adiposity hormones leptin and insulin inhibit anabolic neuropeptides, such as hypothalamic NPY, and chronic NPY administration powerfully increases food intake and body weight. Thus, pharmacological blockade of NPY signaling is a potential antiobesity strategy. Many natural appetite suppressants mediate the reduced expression of hypothalamic neuropeptide Y (NPY) or serum leptin levels [72]. For instance, Kim et al. [71] proved that, in HFD-induced obesity in rats, a crude saponin of Korean ginseng effectively regulated serum leptin and NPY expression in the rat hypothalamus. Limited number of reports were published with regard to interaction of natural substances with appetite suppressing and appetite stimulating molecules.

\subsubsection{Monoamine Neurotransmitters}

Body weight regulation through appetite control is a multifactorial event resulting from neurological and hormonal interrelationships. A line of evidence indicates that serotonin, histamine, dopamine, and their associated receptor activities are closely associated with satiety regulation. Serotonin is a monoaminergic neurotransmitter that modulates numerous sensory, motor, and behavioral processes, acting through a family of at least fourteen 5-HT receptor subtypes. These receptors may enable researchers to better target their searches for drugs that treat obesity through energy intake reduction [73]. Agents that act via peripheral satiety peptide systems, alter the various hypothalamic neuropeptides' CNS levels, or alter the key CNS appetite monoamine neurotransmitters' levels may be suitable candidates for drugs that will suppress appetite [74,75]. Green tea and its constituents (catechins, such as epigallo catechin (EGC) and epigallo catechin gallate (EGCG), have received tremendous attention [76,77], as several lines of evidence suggest EGCG to stimulate thermogenesis through inhibition of the catechol-O-methyltransferase enzyme involved in degradation of norepinephrine [43,57,73,78,79].

Natural hydroxycitric acid (HCA), prepared from Garcinia cambosia, is a potential natural appetite sup- 
pressant. HCA is a competitive inhibitor of adenosine 5triphosphate-citrate lyase, leading to a deceased acetyl coenzyme A production and decreased fatty acid synthesis. HCA is also thought to suppress feed intake via loss of apetite by stimulation of liver gluconeogenesis. HCA is also reported to act by increasing the availability of 5-hydroxytryptamine or serotonin, serotonin is a neurotransmitter implicated in regulating eating behavior and appetite control [24]. Central metabolism of glucose also suppresses food intake, mediated by the hypothalamic

Table 2. Herbal products for weight management with human studies.

\begin{tabular}{|c|c|c|c|c|c|c|}
\hline Author & $\begin{array}{c}\text { Name of } \\
\text { the herbal } \\
\text { product }\end{array}$ & Formulation information & Study/Method & Subjects & Dose/Duration & Result \\
\hline $\begin{array}{l}\text { Singh et al., } \\
\text { [82] }\end{array}$ & Ayurslim & $\begin{array}{l}\text { Garcinia cambogia, } \\
\text { Balsamodendron mukul, } \\
\text { Gymnema sylvestre, } \\
\text { Terminalia chebula, } \\
\text { Trigonella foenum-graecum }\end{array}$ & $\begin{array}{l}\text { Phase IV clinical } \\
\text { trial }\end{array}$ & $\begin{array}{l}42 \text { obese patients } \\
\text { of either sex }\end{array}$ & $\begin{array}{l}2 \text { capsules, twice } \\
\text { daily for } 6 \text { months }\end{array}$ & $\begin{array}{l}\text { Significant effect in } \\
\text { reducing body weight } \\
\text { and lipid levels }\end{array}$ \\
\hline $\begin{array}{l}\text { Godard et al., } \\
\text { [83] }\end{array}$ & & $\begin{array}{l}\text { Forslean from Coleus } \\
\text { forskohlii root }\end{array}$ & $\begin{array}{c}\text { Randomized, } \\
\text { double-blind, } \\
\text { placebo-controlled } \\
\text { study }\end{array}$ & $\begin{array}{l}30 \text { men who were } \\
\text { overweight/obese }\end{array}$ & $\begin{array}{l}250 \text { mg of extract } \\
\text { twice a day for a } \\
\text { 12-week period }\end{array}$ & $\begin{array}{l}\text { Causes positive changes } \\
\text { in body composition in } \\
\text { overweight and obese } \\
\text { adult men }\end{array}$ \\
\hline $\begin{array}{l}\text { Lieberman, } \\
\text { [84] }\end{array}$ & Forslean & $\begin{array}{l}\text { 250-mg capsule of a } \\
\text { standardized extract of Coleus } \\
\text { forskohlii [forskolin ( } 25 \mathrm{mg}) \text { ] }\end{array}$ & Open blind study & $\begin{array}{l}6 \text { overweight, } \\
\text { but otherwise } \\
\text { healthy, women }\end{array}$ & $\begin{array}{l}1 \text { capsule in the } \\
\text { morning and } 1 \text { in } \\
\text { the evening, } 30 \\
\text { minutes before a } \\
\text { meal. For } 4 \text { - } 8 \text { weeks }\end{array}$ & $\begin{array}{l}\text { Mean values for body } \\
\text { weight and fat content were } \\
\text { significantly decreased }\end{array}$ \\
\hline $\begin{array}{l}\text { Henderson et } \\
\text { al., [85] }\end{array}$ & & $\begin{array}{l}250 \text { mg of ForsLean, } \\
\text { supplying } 25 \text { mg of forskolin }\end{array}$ & $\begin{array}{l}\text { Double blinded } \\
\text { placebo controlled } \\
\text { randomized study }\end{array}$ & $\begin{array}{l}60 \text { obese male and } \\
\text { female volunteers }\end{array}$ & $\begin{array}{l}1 \text { capsule twice } \\
\text { daily for } 12 \text { weeks }\end{array}$ & $\begin{array}{l}\text { Total body weight } \\
\text { significantly decreased }\end{array}$ \\
\hline Brown, [86] & Lipotrim & $\begin{array}{l}\text { Chromium } 100 \mathrm{mcg} \text {, } \\
\text { Garcinia cambogia fruit } \\
\text { extract } 50 \mathrm{mg} \text {. }\end{array}$ & NA & $\begin{array}{l}72 \text { patients of } \\
\text { which } 58(80.5 \%) \\
\text { completed the diet } \\
\text { and } 39 \text { attended } \\
\text { follow-up. }\end{array}$ & NA & $\begin{array}{l}\text { Sixteen of the } 39 \text { patients } \\
\text { had a similar weight from } \\
\text { when they started, three had } \\
\text { gained more than } 6 \mathrm{~kg} \text {, } \\
\text { seven had lost } 6 \text { to } 12 \mathrm{~kg} \text {, } \\
\text { and } 13 \text { had lost more than } \\
12 \mathrm{~kg} \text {. }\end{array}$ \\
\hline $\begin{array}{l}\text { Udani et al., } \\
\text { [87] }\end{array}$ & Phase 2 & $\begin{array}{l}\text { Water-extract of a common } \\
\text { white bean (Phaseolus } \\
\text { vulgaris) }\end{array}$ & $\begin{array}{c}\text { Randomized, } \\
\text { double-blind, } \\
\text { placebo-controlled } \\
\text { study }\end{array}$ & $\begin{array}{c}\text { Adults of } 35 \\
\text { females, } 4 \text { males }\end{array}$ & $\begin{array}{l}1500 \text { mg Phase } 2 \\
\text { twice daily with } \\
\text { meals for } 8 \text { weeks }\end{array}$ & $\begin{array}{l}\text { Treated group lost an } \\
\text { average of } 3.79 \text { lbs (average } \\
\text { of } 0.47 \text { lb per week) } \\
\text { compared with the placebo } \\
\text { group, which lost an average } \\
\text { of } 1.65 \text { lbs (average of } 0.21 \\
\text { lb per week). Triglyceride } \\
\text { levels in the Phase } 2 \text { group } \\
\text { were reduced an average of } \\
26.3 \text { mg/dL, more than three } \\
\text { times greater a reduction in } \\
\text { the placebo group }\end{array}$ \\
\hline $\begin{array}{l}\text { Ignjatovic, } \\
\text { [88] }\end{array}$ & Slimax & $\begin{array}{l}\text { Aqueous extract of Hordeum } \\
\text { vulgare, Polygonatum } \\
\text { multiflorum, Dimocarpus } \\
\text { longan, Ligusticum sinense, } \\
\text { Lilium brownii and Zingiber } \\
\text { officinale }\end{array}$ & $\begin{array}{l}\text { Double-blind } \\
\text { experimental } \\
\text { method }\end{array}$ & Human Subjects & Six week period & $\begin{array}{l}\text { Significant decrease in } \\
\text { parameters such as body } \\
\text { weight, waist and hip } \\
\text { circumference, and Body } \\
\text { Mass Index (BMI), in all } \\
\text { subjects tested }\end{array}$ \\
\hline $\begin{array}{l}\text { Toromanyan } \\
\text { et al., [89] }\end{array}$ & Slim339 & $\begin{array}{l}\text { Proprietary blend of Garcinia } \\
\text { cambogia extract with calcium } \\
\text { pantothenate (standardized for } \\
\text { the content of hydroxycitric } \\
\text { acid and pantothenic acid) and } \\
\text { extracts of Matricaria } \\
\text { chamomilla, Rosa damascena, } \\
\text { Lavandula officinalis and } \\
\text { Cananga odorata }\end{array}$ & $\begin{array}{l}\text { Double-blind, } \\
\text { randomized, } \\
\text { parallel-group, } \\
\text { placebo-controlled } \\
\text { study }\end{array}$ & 30 subjects & $\begin{array}{l}1 \text { tablet of Slim339 } \\
\text { three times per } \\
\text { day ( } 60 \text { - } 90 \text { min } \\
\text { before a meal), } \\
\text { for } 60 \text { days }\end{array}$ & $\begin{array}{l}\text { Daily oral } \\
\text { self-administration of } \\
\text { Slim339 in the community } \\
\text { reduced body weight in } \\
\text { overweight and obese } \\
\text { healthy human subjects }\end{array}$ \\
\hline
\end{tabular}


AMPK/malonyl-CoA signaling system [80]. Central administration of glucose increases hypothalamic malonyl-CoA, decreases orexigenic neuropeptide expression, and suppresses food intake. Centrally-administered fructose provokes feeding, via the AMPK/malonyl-CoA signaling pathway. Thus, decoctions prepared from natural sources containing excessively high fructose levels may suppress the hypothalamic malonyl-CoA signaling pathway, thereby exerting an orexigenic effect $[80,81]$.

\section{The Probable Reasons for Obese Person to Prefer Herbal Products for Weight Management}

1) Health benefits of weight loss without any side effects.

2) Less demanding than accepted lifestyle changes, such as exercise and diet.

3) Easily available without a prescription.

4) More easily accepted than a professional consultation with a physician or a nutritionist.

5) $100 \%$ natural origin and perception that natural means safe.

\section{Remarks on Available Information about Herbal Treatment for Obesity}

For many of the herbal weight loss products, there is little published information and there have been no clinical trials or the level of evidence is limited. Some of the herbal products fall under an acceptable level of evidence viz., clinical trials and with no scientific background or scientific rational.

Table 2 compiles available clinical trial literature on various herbal products which have weight reducing effects. Few of the products, which underwent clinical trial, have significant weight reduction as an overall result. The other products have shown comparatively good results in pre clinical studies but lack clinical studies. There are several products in the market claimed to have remarkable weight reducing effects, however there is no supporting published pre clinical and clinical data evidences.

\section{An Ideal Herbal Remedy for Obesity: A Proposal}

Herbal products for weight reduction may be effective in the management of obesity and associated disorders. Consistent and safe herbal product for weight reduction is a need of developed and developing countries. In our literature survey, herbal products showed potential effects on weight control. However, for the majority of products, more data are needed to assess the suitability as an anti obesity product. We have attempted to provide salient futures for an ideal herbal product for the management of obesity.

1) Should bring down the body weight by $10 \%$ over placebo in a well designed randomized placebo controlled clinical trial.

2) Should show evidence of improvement of bio markers like blood pressure, lipids and glycemia.

3) Should have known mechanism of action.

4) Should be standardized with bioactive phytochemicals which is/are responsible for anti obesity activity.

5) Should not have any kind of side effects.

\section{Conclusion}

There are several plants described in ayurveda for weight management. But so far, no systematic and well designed screening is attempted to come up with an effective herbal weight loss product. A better understanding in the existing evidence based science on herbs will further guide a qualitative research in obesity management that will attract the end users by the effective benefits. True randomized, double blinded, placebo-controlled clinical trials using herbal products will demonstrate their potential benefits. Significant weight loss after placebo subtraction along with known mechanism of action are required in order to generate conviction amongst users as effective agent for weight management.

\section{REFERENCES}

[1] World Health Organization, "Obesity. Preventing and Managing the Global Epidemic, Report of a WHO Consultation (WHO Technical Report Series 894)," WHO, 2000.

http://www.who.int/nutrition/publications/obesity/WHO_ TRS 894/en/

[2] "Worldwide Obesity Trends—Globesity," http://www.annecollins.com/obesity/causes-of-obesity.ht $\mathrm{m}$

[3] Centre for Public Health Excellence at NICE (UK), National Collaborating Centre for Primary Care (UK), "Obesity: The Prevention, Identification, Assessment and Management of Overweight and Obesity in Adults and Children," National Institute for Health and Clinical Excellence (UK) (NICE Clinical Guidelines, No. 43), 2006. http://www.ncbi.nlm.nih.gov/books/NBK63696/

[4] “Obesity and Overweight,” Fact Sheet No. 311, 2012. http://www.who.int/mediacentre/factsheets/fs311/en/inde x.html

[5] J. Scheen, "From Obesity to Diabetes: Why, When and Who?” Acta Clinica Belgica, Vol. 55, No. 1, 2002, pp. 915.

[6] J. P. Felber and A. Golay, "Pathways from Obesity to Diabetes," International Journal of Obesity Related Metabolism and Disorders, Vol. 26, No. 2, 2002, pp. 39-45. doi:10.1038/sj.ijo.0802126 
[7] G. R. Bhatti, R. Qureshi and S. M. Shah, "Ethnobotany of Calotropis procera with Especial Reference to the People of Nara Desert,” Scientific Sindh, Vol. 5, 1998, pp.13-22.

[8] U. Rahman and K. Zaman, "Medicinal Plants with Hypoglycemic Activity," Journal of Ethnopharmacology, Vol. 26, No. 1, 1989, pp. 1-55. doi:10.1016/0378-8741(89)90112-8

[9] Food and Drug Administration, "FDA Briefing Document NDA 21-888 Zimulti (rimonabant) Tablets, 20 mg Sanofi Aventis Advisory Committee,” 2007. http://www.fda.gov/ohrms/dockets/ac/07/briefing/2007-4 306b1-fda-backgrounder.pdf

[10] D. Cooke and S. Bloom, "The Obesity Pipeline: Current Strategies in the Development of Anti-Obesity Drugs," Nature Reviews Drug Discovery, Vol. 5, No. 11, 2006, pp. 919-931. doi:10.1038/nrd2136

[11] R. M. Pinder, R. N. Brogden, P. R. Sawyer, T. M. Speight and G. S. Avery, "Fenfluramine: A Review of Its Pharmacological Properties and Therapeutic Efficacy in Obesity,” Drugs, Vol. 10, No. 4, 1975, pp. 241-323. doi:10.2165/00003495-197510040-00001

[12] F. Brenot, P. Herve, P. Petitpretz, F. Parent, P. Duroux and G. Simonneau, "Primary Pulmonary Hypertension and Fenfluramine Use,” British Heart Journal, Vol. 70, No. 6, 1993, pp. 537-541. doi:10.1136/hrt.70.6.537

[13] H. M. Connolly, J. L. Crary, M. D. McGoon, D. D. Hensrud, B. S. Edwards, W. D. Edwards and H. V. Schaff, "Valvular Heart Disease Associated with FenfluraminePhentermine," New England Journal of Medicine, Vol. 337, No. 9, 1997, pp. 581-588. doi:10.1056/NEJM199708283370901

[14] B. A. Swinburn, I. Caterson, J. C. Seidell and W. P. James, "Diet, Nutrition and the Prevention of Excess Weight Gain and Obesity," Public Health Nutrition, Vol. 7, No. 1A, 2004, pp. 123-146.

[15] J. P. Park, J. H. Kim, M. K. Park and J. W. Yun, "Potential Agents for Cancer and Obesity Treatment with Herbal Medicines from the Green Garden,” Biotechnology and Bioprocess Engineering, Vol. 16, No. 6, 2011, pp. 10651076. doi:10.1007/s12257-011-0215-3

[16] K. A. Amin and M. A. Nagy, "Effect of Carnitine and Herbal Mixture Extract on Obesity Induced by High Fat Diet in Rats," Diabetology \& Metabolic Syndrome, Vol. 1, No. 17, 2009, pp. 1-14. doi:10.1186/1758-5996-1-17

[17] R. P. Pickering, B. F. Grant, S. P. Chou, and W. M. Compton, "Are Overweight, Obesity, and Extreme Obesity Associated with Psychopathology? Results from the National Epidemiologic Survey on Alcohol and Related Conditions," Journal of Clinical Psychiatry, Vol. 68, No. 7, 2007, pp. 998-1009. doi:10.4088/JCP.v68n0704

[18] F. B. Dickerson, C. H. Brown and J. A. Kreyenbuhl, "Obesity among Individuals with Serious Mental Illness,” Acta Psychiatrica Scandinavica, Vol. 113, No. 4, 2006, pp. 306313. doi:10.1111/j.1600-0447.2005.00637.x

[19] G. E. Simon, M. Von Korff and K. Saunders, “Association between Obesity and Psychiatric Disorders in the US Adult Population,” Archives of General Psychiatry, Vol. 63, No. 7, 2006, pp. 824-830.

doi:10.1001/archpsyc.63.7.824
[20] L. J. Aronne, "Classification of Obesity and Assessment of Obesity-Related Health Risks," Obesity Research, Vol. 10, No. 2, 2002, pp. 105-115. doi:10.1038/oby.2002.203

[21] J. I. Baile and M. J. Gonzalez, "Psychopathological CoMorbidity in Obesity," Anales del Sistema Sanitario de Navarra, Vol. 34, No. 2, 2011, pp. 253-261. doi:10.4321/S1137-66272011000200011

[22] B. Britz, W. Siegfried, A. Ziegler, C. Lamertz, B. M. Herpertz-Dahlmann, H. Remschmidt, H. U. Wittchen and J. Hebebrand, "Rates of Psychiatric Disorders in a Clinical Study Group of Adolescents with Extreme Obesity and in Obese Adolescents Ascertained via a Population Based Study," International Journal of Obesity Related Metabolism and Disorder, Vol. 24, No. 12, 2000, pp. 1707-1714.

[23] J. Lee, K. Chae, J. Ha, B.Y. Park, H. S. Lee, S. Jeong, M Y. Kim and M. Yoon, "Regulation of Obesity and Lipid Disorders by Herbal Extracts from Morus alba, Melissa officinalis, and Artemisia capillaries in High-Fat Diet-Induced Obese Mice,” Journal of Ethnopharmacology, Vol. 115, No. 2, 2008, pp. 263-270. doi:10.1016/j.jep.2007.09.029

[24] D. Gosh, “A Botanical Approach to Managing Obesity,” University of Wollongong, Wollongong, 2009.

[25] P. V. Sharma, “Dravya Guna Vijnana,” Chaukhambha Bharati Academy, Varanasi, 1993.

[26] P. C. Sharma, M. B. Yelne, T. J. Dennis, and A. Joshi, "Database on Medicinal Plants Used in Ayurveda," Central Council for Research in Ayurveda and Siddha, India, 2000.

[27] V. M. Gogte, "Medicinal Plants, Part III in Ayurvedic Pharmacology and Therapeutic Uses of Medicinal Plants (Dravyagunavignyan),” Bhartiya Vidya Bhavan, Mumbai, 2002.

[28] Misra and R. Vaisya, "Bhavaprakasha Nigantu,” Chaukamba Sanskrit Sansthan, Varanasi, 2005.

[29] J. W. Yun, "Possible Anti-Obesity Therapeutics from Nature-A Review," Phytochemistry, Vol. 71, No. 14-15, 2010, pp. 1625-1641. doi:10.1016/j.phytochem.2010.07.011

[30] R. B. Saper, D. M. Eisenberg and R. S. Phillips, ”Common Dietary Supplements for Weight Loss," American Family Physician Journal, Vol. 70, No. 9, 2004, pp. 17311738.

[31] L. L. Ioannides-Demos, L. Piccenna and J. J. McNeil, "Pharmacotherapies for Obesity: Past, Current, and Future Therapies,” Journal of Obesity, Vol. 2011, 2011, Article ID: 179674. doi:10.1155/2011/179674

[32] R. B. Birari and K. K. Bhutani, "Pancreatic Lipase Inhibitors from Natural Sources: Unexplored Potential,” Drug Discovery Today, Vol. 12, No. 19-20, 2007, pp. 879-889. doi:10.1016/j.drudis.2007.07.024

[33] T. Tsujita, H. Takaichi, T. Takaku, S. Aoyama and J. Hiraki, "Antiobesity Action of E-Polylysine, a Potent Inhibitor of Pancreatic Lipase,” Journal of Lipid Research, Vol. 47, No. 8, 2006, pp. 1852-1858. doi:10.1194/jlr.M600168-JLR200

[34] L. K. Han, Y. N. Zheng, M. Yoshikawa, H. Okuda and Y. Kimura, “Anti-Obesity Effects of Chikusetsusaponins Iso- 
lated from Panax japonicus Rhizome," BMC Complementary and Alternative Medicine, Vol. 5, No. 9, 2005, pp. 1-10. doi:10.1186/1472-6882-5-9

[35] L. K. Han, B. J. Xu, Y. Kimura, Y. Zheng and H. Okuda, "Platycodi radix Affects Lipid Metabolism in Mice with High Fat Diet-Induced Obesity,” The Journal of Nutrition, Vol. 130, No. 11, 2000, pp. 2760-2764.

[36] E. Kishino, T. Ito, K. Fujita and Y. Kiuchi, “A Mixture of the Salacia reticulata (Kotala Himbutu) Aqueous Extract and Cyclodextrin Reduces the Accumulation of Visceral Fat Mass in Mice and Rats with High-Fat Diet-Induced Obesity,” Journal of Nutrition, Vol. 136, No. 2, 2006, pp. 433-439.

[37] Y. Ono, E. Hattori, Y. Fukaya, S. Imai and Y. Ohizumi, "Anti-Obesity Effect of Nelumbo nucifera Leaf Extract in Mice and Rats," Journal of Ethnopharmacology, Vol. 106, No. 2, 2006, pp. 238-244. doi:10.1016/j.jep.2005.12.036

[38] H. Y. Kim and M. H. Kang, "Screening of Korean Medicinal Plants for Lipase Inhibitory Activity,” Phytotherapy Research, Vol. 19, No. 4, 2005, pp. 359-361. doi:10.1002/ptr.1592

[39] D. A. Moreno, N. Ilic, A. Poulev and I. Raskin, "Effects of Arachis hypogaea Nutshell Extract on Lipid Metabolic Enzymes and Obesity Parameters,” Life Sciences, Vol. 78, No. 24, 2006, pp. 2797-2803. doi:10.1016/j.lfs.2005.11.012

[40] H. Shimoda, E. Seki and M. Aitani, "Inhibitory Effect of Green Coffee Bean Extract on Fat Accumulation and Body Weight Gain in Mice,” BMC Complementary and Alternative Medicine, Vol. 6, No. 9, 2006, pp. 1-9. doi:10.1186/1472-6882-6-9

[41] L. K. Han, T. Takaku, J. Li, Y. Kimura and H. Okuda, “Anti-Obesity Action of Oolong Tea," International Journal of Obesity and Related Metabolic Disorders, Vol. 23, No. 1, 1999, pp. 98-105. doi:10.1038/sj.ijo.0800766

[42] M. Nakai, Y. Fukui, S. Asami, Y. Toyoda-Ono, T. Iwashita, H. Shibata, T. Mitsunaga, F. Hashimoto and Y. Kiso, "Inhibitory Effects of Oolong Tea Polyphenols on Pancreatic Lipase in Vitro," Journal of Agricultural and Food Chemistry, Vol. 53, No. 11, 2005, pp. 4593-4598. doi:10.1021/jf047814+

[43] F. Thielecke and M. Boschmann, "The Potential Role of Green Tea Catechins in the Prevention of the Metabolic Syndrome-A Review," Phytochemistry, Vol. 70, No. 1, 2009, pp. 11-24. doi:10.1016/j.phytochem.2008.11.011

[44] H. K. Kim, M. Della-Fera, J. Lin and C. A. Baile, "Docosahexaenoic Acid Inhibits Adipocyte Differentiation and Induces Apoptosis in 3T3-L1 Preadipocytes," The Journal of nutrition, Vol. 136, No. 12, 2006, pp. 2965-2969.

[45] M. Spiegelman, E. Hu, J. B. Kim and R. Brun, "PPAR Gamma and the Control of Adipogenesis,” Biochimistry, Vol. 79, No. 2-3, 1997, pp. 111-112. doi:10.1016/S0300-9084(97)81500-3

[46] Y. B. Lombardo and A. G. Chicco, "Effects of Dietary Polyunsaturated n-3 Fatty Acids on Dyslipidemia and Insulin Resistance in Rodents and Humans. A Review," The Journal of Nutritional Biochemistry, Vol. 17, No. 1, 2006, pp. 1-13. doi:10.1016/j.jnutbio.2005.08.002
[47] T. Murase, A. Nagasawa, J. Suzuki, T. Hase and I. Tokimitsu, "Beneficial Effects of Tea Catechins on Diet-Induced Obesity: Stimulation of Lipid Catabolism in the Liver," International Journal of Obesity and Related Metabolic Disorders, Vol. 26, No. 11, 1999, pp. 14591464. doi:10.1038/sj.ijo.0802141

[48] Y. H. Kao, R. A. Hiipakka and S. Liao, "Modulation of Endocrine Systems and Food Intake by Green Tea Epigallocatechin Gallate,” Endocrinology, Vol. 141, No. 3, 2000, pp. 980-987. doi:10.1210/en.141.3.980

[49] K. Sayama, S. Lin, G. Zheng and I. Oguni, "Effects of Green Tea on Growth, Food Utilization and Lipid Metabolism in Mice,” In Vivo, Vol. 14, No. 4, 2000, pp. 481484.

[50] P. J. Chien, Y. C. Chen, S. C. Lu and F. Sheu, "Dietary Flavonoids Suppress Adipogenesis in 3T3-L1 Preadipocytes,” Journal of Food and Drug Analysis, Vol. 13, No. 2, 2005, pp. 168-175.

[51] K. M. Hargrave, C. Li, B. J. Meyer, S. D. Kachman, D. L. Hartzell, M. A. Della-Fera, J. L. Miner and C. A. Baile, "Adipose Depletion and Apoptosis Induced by Trans-10, Cis-12 Conjugated Linoleic Acid in Mice,” Obesity Research, Vol. 10, No. 12, 2002, pp. 1284-1290. doi:10.1038/oby.2002.174

[52] J. T. Hwang, I. J. Park, J. I. Shin, Y. K. Lee, S. K. Lee, H. W. Baik, J. Ha and O. J. Park, "Genistein, EGCG, and Capsaicin Inhibit Adipocyte Differentiation Process via Activating AMP-Activated Protein Kinase,” Biochemical and Biophysical Research Communication, Vol. 338, No. 2, 2002, pp. 694-699. doi:10.1016/j.bbrc.2005.09.195

[53] C. L. Hsu and G. C. Yen, "Induction of Cell Apoptosis in 3T3-L1 Pre-Adipocytes by Flavonoids Is Associated with Their Antioxidant Activity," Molecular Nutrition and Food Research, Vol. 50, No. 11, 2006, pp. 1072-1079. doi:10.1002/mnfr.200600040

[54] J. Y. Yang, M. A. Della-Fera, D. L. Hartzell, C. NelsonDooley, D. B. Hausman and C. A. Baile, "Esculetin Induces Apoptosis and Inhibits Adipogenesis in 3T3-L1 Cells,” Obesity, Vol. 14, No. 10, 2006, pp. 1691-1699. doi:10.1038/oby.2006.194

[55] J. Y. Yang, M. A. Della-Fera, S. Rayalam, S. Ambati, D. L. Hartzell, H. J. Park and C. A. Baile, "Enhanced Inhibition of Adipogenesis and Induction of Apoptosis in 3T3L1 Adipocytes with Combinations of Resveratrol and Quercetin,” Life Sciences, Vol. 82, No. 19-20, 2008, pp. 1032-1039. doi:10.1016/j.lfs.2008.03.003

[56] F. Picard, M. Kurtev, N. Chung, A. Topark-Ngarm, T. Senawong, R. Machado De Oliveira, M. Leid, M. W. McBurney and L. Guarente, "Sirt1 Promotes Fat Mobilization in White Adipocytes by Repressing PPAR-Gamma,” Nature, Vol. 429, No. 6993, 2004, pp. 771-776. doi:10.1038/nature02583

[57] S. Rayalam, M. A. Della-Fera and C. A. Baile, "Phytochemicals and Regulation of the Adipocyte Life Cycle," The Journal of Nutritional Biochemistry, Vol. 19, No. 11, 2008, pp. 717-726. doi:10.1016/j.jnutbio.2007.12.007

[58] J. P. Flatt, "Differences in Basal Energy Expenditure and Obesity,” Obesity, Vol. 15, No. 11, 2007, pp. 2546-2548. doi:10.1038/oby.2007.304 
[59] R. N. Redinger, "Fat Storage and the Biology of Energy Expenditure," Translational Research, Vol. 154, No. 2, 2009, pp. 52-60. doi:10.1016/j.trsl.2009.05.003

[60] B. Cannon and J. Nedergaard, "Brown Adipose Tissue: Function and Physiological Significance,” Physiological Reviews, Vol. 84, No. 1, 2004, pp. 277-359. doi:10.1152/physrev.00015.2003

[61] M. V. Kumar, G. D. Sunvold and P. J. Scarpace, “Dietary Vitamin a Supplementation in Rats: Suppression of Leptin and Induction of UCP1 mRNA," Journal of Lipid Research, Vol. 40, No. 5, 1999, pp. 824-829.

[62] S. S. Yoon, Y. H. Rhee, H. J. Lee, E. O. Lee, M. H. Lee, K. S. Ahn, H. T. Lim and S. H. Kim, "Uncoupled Protein 3 and p38 Signal Pathways Are Involved in Anti-Obesity Activity of Solanum tuberosum L. cv. Bora Valley,” Journal of Ethnopharmacology, Vol. 118, No. 3, 2008, pp. 396-404. doi:10.1016/j.jep.2008.05.014

[63] G. Dulloo, "Ephedrine, Xanthines and Prostaglandin-Inhibitors: Actions and Interactions in the Stimulation of Thermogenesis," International Journal of Obesity and Related Metabolic Disorders, Vol. 17, No. 1, 1993, pp. 35-40.

[64] S. Racotta, J. Leblanc and D. Richard, "The Effect of Caffeine on Food Intake in Rats: Involvement of Corticotropin-Releasing Factor and the Sympatho-Adrenal System," Pharmacology, Biochemistry, and Behavior, Vol. 48, No. 4, 1994, pp. 887-892. doi:10.1016/0091-3057(94)90196-1

[65] T. Kawada, T. Watanabe, T. Takaishi, T. Tanaka and K. Iwai, "Capsaicin-Induced Beta-Adrenergic Action on Energy Metabolism in Rats: Influence of Capsaicin on Oxygen Consumption, the Respiratory Quotient, and Substrate Utilization," Proceedings of the Society for Ex-perimental Biology and Medicine, Vol. 183, No. 2, 1986, pp. 250-256.

[66] D. Langin, “Adipose Tissue Lipolysis as a Metabolic Pathway to Define Pharmacological Strategies against Obesity and the Metabolic Syndrome,” Pharmacological Research, Vol. 53, No. 6, 2006, pp. 482-491. doi:10.1016/j.phrs.2006.03.009

[67] E. Ohkoshi, H. Miyazaki, K. Shindo, H. Watanabe, A. Yoshida and H. Yajima, "Constituents from the Leaf of Nelumbo nucifera Stimulate Lipolysis in the White Adipose Tissue of Mice,” Planta Medica, Vol. 73, No. 12, 2007, pp. 1255-1259. doi:10.1055/s-2007-990223

[68] S. Flier, "Obesity Wars: Molecular Progress Confronts an Expanding Epidemic,” Cell, Vol. 116, No. 2, 2004, pp. 337-350. doi:10.1016/S0092-8674(03)01081-X

[69] G. J. Morton, D. E. Cummings, D. G. Baskin, G. S. Barsh and M. W. Schwartz, "Central Nervous System Control of Food Intake and Body Weight,” Nature, Vol. 443, No. 7109, 2006, pp. 289-295. doi:10.1038/nature05026

[70] F. Di Pierro, A. B. Menghi, A. Barreca, M. Lucarelli and A. Calandrelli, "Green Select Phytosome as an Adjunct to a Low-Calorie Diet for Treatment of Obesity: A Clinical Trial," Alternative Medicine Reviews, Vol. 14, No. 2, 2009, pp. 154-160.

[71] S. O. Kim, S. J. Yun, B. Jung, E. H. Lee, D. H. Hahm, I. Shim and H. J. Lee, "Hypolipidemic Effects of Crude Ex- tract of Adlay Seed (Coix lachrymajobi var. Mayuen) in Obesity Rat Fed High Fat Diet: Relations of TNF-Alpha and Leptin mRNA Expressions and Serum Lipid Levels,” Life Sciences, Vol. 75, No. 11, 2004, pp. 1391-1404. doi:10.1016/j.lfs.2004.03.006

[72] D. S. Weigle, "Pharmacological Therapy of Obesity: Past, Present, and Future," The Journal of Clinical Endocrinology and Metabolism, Vol. 88, No. 6, 2003, pp. 24622469. doi:10.1210/jc.2003-030151

[73] H. Tecott, L. M. Sun, S. F. Akana, A. M. Strack, D. H. Lowenstein, M. F. Dallman and D. Julius, "Eating Disorder and Epilepsy in Mice Lacking 5-HT2c Serotonin Receptors," Nature, Vol. 374, No. 6522, pp. 542-546. doi:10.1038/374542a0

[74] J. C. Halford and J. E. Blundell, "Pharmacology of Appetite Suppression,” Progress in Drug Research, Vol. 54, 2000, pp. 25-58. doi:10.1007/978-3-0348-8391-7_2

[75] K. Wynne, S. Stanley, B. Mc Gowan and S. Bloom, “Appe- tite Control," The Journal of Endocrinology, Vol. 184, No. 2, 2005, pp. 291-318. doi:10.1677/joe.1.05866

[76] S. Wolfram, Y. Wang and F. Thielecke, "Anti-Obesity Effects of Green Tea: From Bedside to Bench,” Molecular Nutrition and Food Research, Vol. 50, No. 2, 2006, pp. 176-187. doi:10.1002/mnfr.200500102

[77] H. S. Moon, H. G. Lee, Y. J. Choi, T. G. Kim and C. S. Cho, "Proposed Mechanisms of (-)-Epigallocatechin-3Gallate for Anti-Obesity," Chemico-Biological Interactions, Vol. 167, No. 2, 2007, pp. 85-98. doi:10.1016/j.cbi.2007.02.008

[78] R. T. Borchardt and J. A. Huber, "Catechol O-methyltransferase. 5. Structure-Activity Relationships for Inhibition by Flavonoids," Journal of Medical Chemistry, Vol. 18, No. 1, 1975, pp. 120-122. doi:10.1021/jm00235a030

[79] M. Boschmann and F. Thielecke, "The Effects of Epigallocatechin-3-Gallate on Thermogenesis and Fat Oxidation in Obese Men: A Pilot Study," Journal of the American Collage of Nutrition, Vol. 26, No. 4, 2007, pp. 389-395.

[80] D. Lane and S. H. Cha, "Effect of Glucose and Fructose on Food Intake via Malonyl-CoA Signaling in the Brain,” Biochemical and Biophysical Research Communication, Vol. 382, No. 1, 2009, pp. 1-5. doi:10.1016/j.bbrc.2009.02.145

[81] S. H. Cha, M. Wolfgang, Y. Tokutake, S. Chohnan and M. D. Lane, "Differential Effects of Central Fructose and Glucose on Hypothalamic Malonyl-CoA and Food Intake," Proceedings of the National Academy of Sciences of the United States of America, Vol. 105, No. 44, 2008, pp. 16871-16875. doi:10.1073/pnas.0809255105

[82] K. Singh, P. S. Patki and S. K. Mitra, "Evaluation of Clinical Efficacy of AyurSlim on Body Weight, Body Mass Index, Lipid Profile and Skin Fold Thickness: A Phase IV Clinical Study,” The Antiseptic, Vol. 105, No. 5, 2005, pp. 241-243.

[83] M. P. Godard, B. A. Johnson and S. R. Richmond, "Body Composition and Hormonal Adaptations Associated with Forskolin Consumption in Overweight and Obese Men,” Obesity Research, Vol. 13, No. 8, 2005, pp. 1335-1343. 
doi:10.1038/oby.2005.162

[84] S. A. Lieberman, "A New Potential Weapon for Fighting Obesity. Forskolin-The Active Diterpene in Coleus," Alternative Complementary Therapy, Vol. 10, No. 6, 2004, pp. 330-333. doi:10.1089/act.2004.10.330

[85] S. Henderson, B. Magu, C. Rasmussen, S. Lancaster, C. Kerksick, P. Smith, C. Melton, P. Cowan, M. Greenwood, C. Earnest, A. Almada, P. Milnor, T. Magrans, R. Bowden, S. Ounpraseuth, A. Thomas and R. B. Kreider, "Effects of Coleus Forskohlii Supplementation on Body Composition and Hematological Profiles in Mildly Overweight Women," Journal of International Society for Sports Nutrition, Vol. 2, No. 2, 2005, pp. 54-62. doi:10.1186/1550-2783-2-2-54

[86] J. Brown, "Lipotrim Diet in General Practice,” British Journal of General Practice, Vol. 49, No. 439, 1999, pp.
147-148.

[87] J. Udani, M. Hardy, and D. C. Madsen, "Blocking Carbohydrate Absorption and Weight Loss: A Clinical Trial Using Phase $2^{\mathrm{TM}}$ Brand Proprietary Fractionated White Bean Extract," Alternative Medicine Review, Vol. 9, No. 1, 2004, pp. 63-69.

[88] V. Ignjatovic, E. Ogru, M. Heffernan, R. Libinaki, Y. Lim, and F. Ng, "Studies on the Use of 'Slimax', a Chinese Herbal Mixture, in the Treatment of Human Obesity,” Pharmaceutical Biology, Vol. 38, No. 1, 2000, pp. 30-35.

[89] E. Toromanyan, G. Aslanyan, E. Amroyan, E. Gabrielyan, and A. Panossian, "Efficacy of Slim339 ${ }^{\circledR}$ in Reducing Body Weight of Overweight and Obese Human Subjects," Phytotherapy Research, Vol. 21, No. 12, 2007, pp. 1177-1181. doi:10.1002/ptr.2231 